\section{Grete Herlofson}

Generalsekretær

Norske Kvinners Sanitetsforening

\title{
Vi er hverandres nødvendighet
}

Livet vårt er skjørt. I menneskers møte med motbakker trenger vi et samfunn som i fellesskap stiller opp.

«Hvem har sagt at dagene våre skulle være gratis. At de skulle snurre rundt på lykkehjulet i hjertet vårt og hver kveld stoppe på gevinst?» spør den kjente dikteren Kolbjørn Falkeid i diktet Hvor hadde vi det fra?

Det er når dagene ikke lenger er gratis, at helsevesen og leger i hovedsak møter sine pasienter. Hele mennesker, som ofte oppsøker helsevesenet i redsel, med smerte og med usikkerhet. Norsk helsevesen er fantastisk. Vi får stort sett den hjelpen vi trenger for den diagnosen som blir satt, så langt det lar seg gjøre. Men helse er så mye mer enn en diagnose. Helse er trivsel, helse er kunnskap, helse er nettverk, helse er engasjement, helse er aktivitet, helse er komplekst.

| 18 år har jeg jobbet i frivillige humanitære organisasjoner. Organisasjoner som møter mennesker i sårbare faser av livet. Mennesker som er rotløse, fortvilet, lever i utenforskap, har fysiske eller psykiske helseutfordringer, lever med sorg eller redsel. I dag er jeg så heldig å være generalsekretær for Norske Kvinners Sanitetsforening. Sanitetskvinnene og andre frivillige organisasjoner har historisk sett hatt en avgjørende rolle i å sikre grunnleggende helsetilbud til landets innbyggere. Da Fredrikke Marie Qvam (1843-1938) etablerte Norske Kvinners Sanitetsforening for 120 år siden, hadde ikke staten mulighet til å gi grunnleggende helsetjenester til sine innbyggere. Sanitetskvinnene og andre frivillige organisasjoner gikk foran og etablerte helsetjenester som blant annet tuberkulosesykehus, helse- stasjoner for mor og barn og psykiatriske behandlingsinstitusjoner. Datidens helsevesen var et tettvevd samspill mellom det offentlige tilbudet og de tjenestene frivillige organisasjoner etablerte og drev.

Det store spørsmålet er om det fortsatt er behov for frivillige organisasjoner i et land som er styrtrikt av oljekroner? Et land hvor myndighetene har lovfestet og overtatt mange av de helsetilbudene frivilligheten har drevet frem? For meg er svaret på spørsmålet enkelt, og det er ja. Ingen kan erstatte frivillige organisasjoners unike evne til å gå foran, påpeke svakheter og brøyte vei innenfor helsetjenestene. Ingen kan erstatte frivilligheten og den helseeffekten det likeverdige møtet har. Enten det er for minoritetskvinner som forteller at møtet med en frivillig sanitetskvinne var det første møte med en nordmann som ikke fikk betalt for å være sammen med henne. Eller det er besøksvennen som bes $\emptyset$ ker ensomme eldre fordi man ønsker å bruke fritiden sin på møtet, ikke fordi det er en del av en betalt jobb. Vi mennesker trenger begge deler. Et trygt, profesjonelt, åpent og pasientvennlig helsevesen, og en velutviklet, åpen, inkluderende og frivillig sektor. Når dagene ikke lengre er gratis, utfyller vi hverandre.

«Hvem sa at livet vårt skulle være lett å bygge ferdig? At mursteinene var firkantete ballonger som føk på plass, hvem sa det, hvor har vi det fra?» sier Kolbjørn Falkeid videre. Vi møter alle motstand på veien. Møtet med helsevesenet er avgjørende viktig når livet strammer seg til, når mursteinene ikke fyker på plass.

Mitt siste møte med helsevesenet var sammen med min far da hans liv gikk mot slutten. Han ble en voksen mann og møtte døden sent i livet på en intensivavdeling ved ett av landets gode sykehus. I den siste tiden var både pappa og vi i familien var helt avhengige av profesjonelle leger og sykepleiere som behandlet pappa som pasient, men som også var viktige støttespillere for oss pårørende. Vi ble stilt overfor krevende valg knyttet til pappas videre behandlingsløp. Livet var ikke lett å bygge ferdig. Råd, varme, omtanke og oppfølging fra sykehuspersonalet var fantastisk. Sykepleieren som ringte min mor om lag en måned etter at pappa døde fra oss, stilte viktige spørsmål. «Har du mennesker rundt deg, har du nettverk, innhold i hverdagen, noen å snakke med i sorgen?» Det går bra med min mor. Hun har nettverket og vennene, familien og naboene - det viktigste i denne fasen og et behov som ikke helsevesenet kan eller skal dekke. Da trenger vi et frivillig og inkluderende storsamfunn som ser og ivaretar - sammen med det offentlige. En nødvendighet også her.

«Det var piller for alt, nerver, vedvarende hoste og anemi. Men hvem sa at snarveiene støtt var kjørbare, at fjellovergangene aldri snødde til og at nettopp vi skulle slippe å sitte fast i tunnelen?» avslutter Kolbjørn Falkeid diktet. Og han har så rett. Av og til er medisin i form av piller det riktigste, mens i andre situasjoner kan den viktigste medisinen for et menneske være et annet menneske. Som står ved, løfter, støtter og heier når vi i perioder møter snødekte fjelloverganger

Gode samfunn skapes i relasjon mellom mennesker, leger, sykepleiere, psykologer, frivillige, naboer, klassekamerater, familie og venner. Da kan vi mennesker mer robuste og bedre forberedt - møte dager som ikke er gratis. Det skaper det gode Norge.

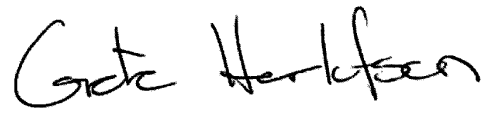

